\title{
Characterization of Mycobionts of Photomorph Pairs in the Peltigerineae (Lichenized Ascomycetes) Based on Internal Transcribed Spacer Sequences of the Nuclear Ribosomal DNA
}

\author{
Bernard Goffinet ${ }^{1}$ and Randall J. Bayer \\ Department of B iological Sciences, The University of Alberta, Edmonton, Alberta, T6G 2E9 Canada
}

Accepted for publication April 7, 1997

Goffinet, B., and Bayer, R. J . 1997. Characterization of mycobionts of photomorph pairs in the Peltigerineae (lichenized ascomycetes) based on internal transcribed spacer sequences of the nuclear ribosomal DNA. Fungal Genetics and Biology 21, 228-237. The The "one fungus-two photomorphs" hypothesis suggests that certain lichenized fungi can establish a symbiotic relationship with either a eukaryotic or a prokaryotic photobiont. Such pairs of photomorphs are well know from cephalodiate Peltigerineae. Using an ascomycete-specific primer we amplified the internal transcribed spacer region of the nrDNA repeat of the mycobiont from total "lichen DNA" extracts of Peltigera malacea, photomorphs of $P$. aphthosa, $P$. britannica, and $P$. leucophlebia, Nephroma expallidum, and photomorphs of $N$. arcticum. Comparisons of 5.85 sequences suggest that the sequences obtained belong to the mycobiont and thus, that the ascomycetespecific primer is adequate for amplifying fungal DNA from total lichen-DNA extracts. The strict identity of nucleotide sequences of the internal transcribed spacer region of the nrDNA repeat between joined-photomorphs supports the one fungus-two photomorphs hypothesis. Photomorphs may thus primarily reflect phenotypic plasticity of photomorphic fungi in response to changing environmental conditions. The

\footnotetext{
${ }^{1}$ To whom correspondence and reprint requests should be addressed at present address: Department of Botany, P.O. Box 90339, Duke University, Durham, NC, 27708. F ax: 919660 7293. E-mail: goffinet@duke.edu.
}

cyanomorph recently reported for $P$. leucophlebia is shown to be based on a misidentified specimen of $P$. aphthosa. Comparisons of the ITS sequences further supports recognizing $P$. aphthosa, $P$. britannica, and $P$. leucophlebia at the species rather than the infraspecific level. @ 1997 Academic Press

Index Descriptors: Peltigerineae; Peltigera; Nephroma; photomorph; taxonomy; nrDNA; ITS; evolution; lichen.

The lichen symbiosis is a complex mutualistic relationship typically between two, but also commonly among three, four, or even more partners (H awksworth, 1988a). One form of multiple symbiosis involves one mycobiont and two distinct photobionts. In such triple symbiosis the fungus is lichenized either with two different strains of the same photobiont (L eizerovich et al., 1990), or two distantly related taxa, e.g., a cyanobacterium and a green alga. In the latter case, the primary photobiont is typically a chlorococcalean alga, while the cyanobacterium is restricted to a subordinate association, called a cephalodium. Cephalodia are established either internally or externally (Jordan, 1972) and are found in about 500 taxa distributed among five orders ( $J$ ames and $H$ enssen, 1976). Species of most genera of the Peltigerineae (sensu Tehler, 1996) can further develop thalli either exclusively with Nostoc (a cyanobacterium), or with Nostoc and a species of Coccomyxa (a green alga) simultaneously.

Unlike any other suborder of lichenized fungi, the 
Peltigerineae include genera such as L obaria, N ephroma, Peltigera, Pseudocyphellaria, Solorina, and Sticta, in which either a cyanobacterium or a green alga can serve as the primary photobiont. Lichenization with a green alga is followed in all these genera by the development of cephalodia. Furthermore, joined green and blue-green lobes (hereafter called chloromorph and cyanomorph, respectively, or photomorph-term introduced by $L$ aundon, 1995- when the nature of the photobiont is not specified) or independent thalli that are chemically and/or morphologically similar except for the nature of the photobiont, have been reported for all these genera (see James and H enssen, 1976, and Jahns, 1988, for a review). Alternative photomorphs can differ in their growth form (e.g., L obaria, Jordan, 1972, and Sticta, Galloway, 1994); their morphology (e.g., Peltigera aphthosa-group; H oltanH artwig, 1993; Vitikainen, 1994; Goward et al., 1995; and Pseudocyphellaria, Renner and Galloway, 1982; Galloway, 1988), their anatomy (e.g., P. venosa; Ott, 1988), their chemistry (e.g., Nephroma arcticum; Tønsberg and Holtan$\mathrm{H}$ artwig, 1983; see also Renner, 1982), their habitat preferences (White and James, 1987) and the cytology of the actual interactions between symbionts (H onegger, 1982, 1985). Whether all these differences are induced by the alternative photobiont or whether some of these reflect the presence of two genetically distinct mycobionts is not clear.

M orphology and chemistry alone cannot provide unambiguous evidence for the genetic identity of mycobionts involved in alternative photomorphs. Armaleo and Clerc (1991) provided the first molecular data in support of the "one fungus- two photomorphs" hypothesis. H owever, their conclusion relied on hybridization of restriction digests of total DNA and of restriction site comparisons of PCR products. D espite the high stringency employed in the hybridization experiment, the authors could not exclude the possibility of sequence divergence. Restriction sites represent only a small fraction of available characters for any given sequence and may not offer sufficient resolution to exclude the presence of two species. In order to address the "one-fungus-two photomorphs" hypothesis using actual D N A sequence data, we used fungus-specific primers for the amplification of a portion of the nuclear D N A from a total lichen D N A extract. F ungus-specific primers were initially designed by Gargas and Taylor (1992) and Gardes and Bruns (1993) for studying symbiotic or parasitic fungi, and recently, Egger (1995) designed primers specific to ascomycetes for studying ectomycorrhizal communities.

The nrDNA repeat includes the genes coding for the RNAs of the small and large subunits of the ribosome, an internal transcribed spacer (ITS), the $5.8 \mathrm{~S}$ gene, and an intergenic spacer (IGS) separating two consecutive repeats (see Zimmerman and D ahlberg, 1996, for extensive review on nrD N A repeat). Concerted evolution due to homogenization (H illis and Dixon, 1991) may allow for a mutation that is not selected against to be integrated into the primary sequence of every copy of the $\mathrm{nrDN}$ A repeat (but see also Sanders et al., 1995). The amount of variation of a molecule depends on the stringency of functional constraints affecting the transcribed product. Despite being noncoding, the ITSs are not void of structural constraints as suggested by the nonrandom distribution of mutations (Torres et al., 1990; van der Sande et al., 1992; Liu and Schardl, 1994; Schlötterer et al., 1995; Buckler and H oltsford, 1996). These moderate selection pressures have lead to a level of variation in the ITS that is presumed to be negligible within most species but significant between species. ITS sequence data have been used for phylogenetic reconstructions within fungal genera (H ibbett, 1992, for initial review; Carbone and Kohn, 1993; Zambino and Szabo, 1993; Messner et al., 1995) and particularly for phylogenetic studies in vascular plants (see Baldwin et al., 1995, for review). ITS sequences of lichenized fungi were first reported for Cladonia chlorophaea by De Priest and Been (1992; ITS-1) and Niu and Wei (1993) were the first to address a taxonomic hypothesis in lichenology (i.e., the status of Lasallia rossica D ombr. and L. papullosa (Ach.) L lano) using ITS sequence variation.

The main objectives of this study are to: (1) test the applicability of fungus-specific primers designed for mycorrhizal ascomycetes (E gger, 1995) for the amplification of the ITS region of lichenized fungi using a total lichen D N A template; and (2) test the hypothesis "one fungus-two photomorphs" based on nucleotide sequences of the ITSs and $5.8 \mathrm{~S}$ gene of members of photomorph pairs in the Peltigerineae.

\section{MATERIALS AND METHODS}

DNA extraction. Thallus fragments of composite photomorphs were sampled from fresh or dried herbarium collections of photomorphic species of Peltigera and $\mathrm{Ne}$ phroma (Table 1). DNA was also extracted from putative related taxa, P. malacea and N. expallidum, to assess the degree of divergence among related species. The lichen samples were soaked in distilled water and all contaminating plant material was removed under a dissecting microscope. The samples were then air-dried overnight and 
TABLE 1

Taxa for Which Sequences of the ITS Region $\mathrm{H}$ ave Been Obtained in This Study

\begin{tabular}{|c|c|c|}
\hline Taxon & $\begin{array}{c}\text { Genbank } \\
\text { accession no. }\end{array}$ & Voucher \\
\hline \multicolumn{3}{|l|}{ Nephroma arcticum (L.) } \\
\hline $\begin{array}{l}\text { Torss. (joined photo- } \\
\text { morphs) }\end{array}$ & U 92881 & $\begin{array}{c}\text { Canada, T. Goward } \\
\text { 92-354 (U BC) }\end{array}$ \\
\hline $\begin{array}{l}\text { Nephroma expallidum } \\
\text { (N yl.) N yl. }\end{array}$ & U 92880 & Canada, G offinet 3520 \\
\hline $\begin{array}{l}\text { Peltigera aphthosa (L.) } \\
\text { Willd. (sample 1; chlo- } \\
\text { romorph) }\end{array}$ & U 73492 & Canada, G offinet 3949-b. \\
\hline \multicolumn{3}{|l|}{ Peltigera aphthosa (L.) } \\
\hline $\begin{array}{l}\text { Willd. (sample 2; joined } \\
\text { photomorphs) }\end{array}$ & & $\begin{array}{l}\text { Canada, G oward 94-1018 } \\
\text { (UBC) }\end{array}$ \\
\hline \multicolumn{3}{|l|}{$\begin{array}{l}\text { Peltigera britannica } \\
\text { (Gyelnik) H olt.-H art. \& }\end{array}$} \\
\hline $\begin{array}{l}\text { Tønsb. (joined photo- } \\
\text { morphs) }\end{array}$ & U 73493 & $\begin{array}{l}\text { Canada, Goward 92-276 } \\
\text { (UBC) }\end{array}$ \\
\hline \multicolumn{3}{|l|}{ Peltigera leucophlebia } \\
\hline $\begin{array}{l}\text { (N yl.) Gyelnik (joined } \\
\text { photomorphs) }\end{array}$ & & $\begin{array}{l}\text { Canada, G oward 92-319 } \\
\quad(\text { U BC) }\end{array}$ \\
\hline \multicolumn{3}{|l|}{$\begin{array}{l}\text { Peltigera leucophlebia } \\
\text { (N yl.) Gyelnik (sample }\end{array}$} \\
\hline 1; chloromorph) & U 73494 & Canada, G offinet 3949-c. \\
\hline $\begin{array}{l}\text { Peltigera leucophlebia } \\
\text { (N yl.) Gyelnik (sample }\end{array}$ & & \\
\hline 2; chloromorph) & U 73495 & Canada, G offinet 3747. \\
\hline $\begin{array}{l}\text { Peltigera leucophlebia } \\
\text { (N yl.) Gyelnik (sample }\end{array}$ & & \\
\hline 3; chloromorph) & U 73496 & F rance, Sérusiaux 10955. \\
\hline Peltigera malacea (Ach.) & & \\
\hline Funck & U 73491 & Canada, G offinet 3984. \\
\hline
\end{tabular}

Note. Voucher specimens are kept in the private herbarium of $B$. $\mathrm{G}$ offinet unless otherwise noted.
Iyophilized prior to the extraction. The extraction protocol is based on modifications of Doyle and Doyle's method (1987; modified protocol available from senior author). The DNA was then suspended in $100 \mu \mathrm{l}$ of TE at $65^{\circ} \mathrm{C}$ for $10 \mathrm{~min}$ and kept at $-20^{\circ} \mathrm{C}$. The DNA concentration was determined by fluorometry following the manufacturer's instruction (TKO 100 mini-fluorometer, H oefer).

PCR-DNA amplification. The amplification reaction was performed in $50 \mu \mathrm{l}$ vol including $50 \mathrm{mM} \mathrm{KCl}, 10 \mathrm{mM}$ Tris- $\mathrm{HCl}, 0.1 \%$ Triton, $5 \%$ glycerol, $2.5 \mathrm{mM} \mathrm{M} \mathrm{gCl} 2,20 \mu \mathrm{M}$ of each dNTP, $0.2 \mu \mathrm{M}$ of the universal primer ITS5 (White et al., 1990) and the ascomycete-specific primer NL6A (E gger, 1995; Fig. 1), and 0.2 to 30.0 ng of template D NA. This solution was overlaid with $30 \mu$ of mineral oil. The samples were exposed to the following temperature profiles using a Grant thermal cycler: one cycle of $94^{\circ} \mathrm{C}$ for 3 min and $85^{\circ} \mathrm{C}$ for 4 min during which 1 unit of Taq D NA Polymerase (Promega) would be added to each tube, and 30 cycles of $94^{\circ} \mathrm{C}$ for $1 \mathrm{~min}, 55^{\circ} \mathrm{C}$ for $1 \mathrm{~min}, 72^{\circ} \mathrm{C}$ for $2 \mathrm{~min}$, and finally one segment of $72^{\circ} \mathrm{C}$ for $10 \mathrm{~min}$, after which the samples were kept at $15^{\circ} \mathrm{C}$ before being placed at $4^{\circ} \mathrm{C}$ until electrophoresis. Single-stranded "forward" and "reverse" templates for the sequencing reaction were prepared via an asymmetric PCR amplification following the same protocol as above, except that only one of the two PCR-primers was included in the reaction. The singlestranded product was precipitated with 20\% PEG/2.5 M $\mathrm{N} \mathrm{aCl}$, washed first with $70 \% \mathrm{EtOH}$, then with $95 \% \mathrm{E} \mathrm{tOH}$ before being suspended in $7 \mu \mathrm{l}$ of TE (M organ and Soltis, 1993).

Sequencing and alignment. We used the "universal" primers ITS1 and ITS4 (White et al., 1990) to sequence the spacer ITS-1 and 5.8S gene from the forward strand and the spacer ITS- 2 and the $5.8 \mathrm{~S}$ gene from the reverse strand, respectively (F ig. 1). The single-stranded template

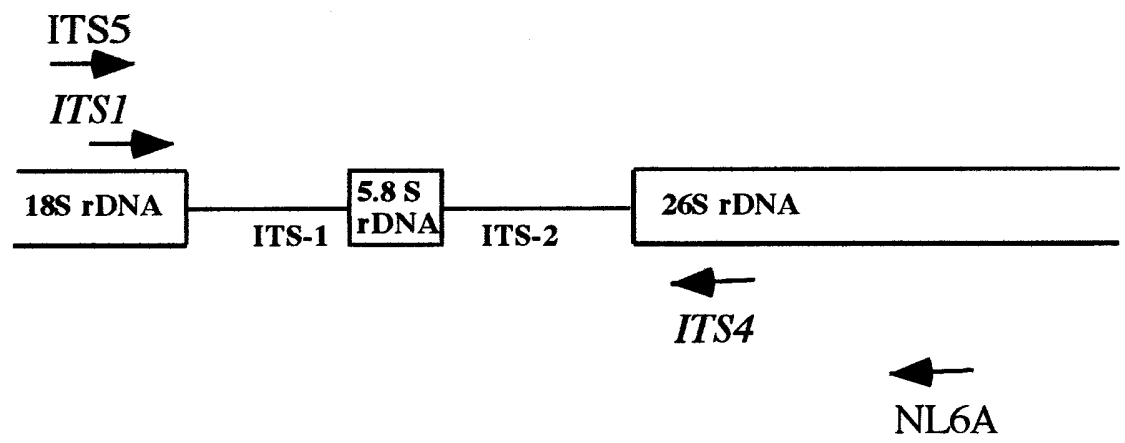

FIG. 1. L ocalization of PCR (plain) and sequencing (italicized) primers used for the amplification and sequencing reaction of the ITS region from total lichen extract of species of Peltigera and N ephroma. 
was sequenced using the dideoxy chain termination method (Sanger et al., 1977) with the T 7 D N A Polymerase Version 2.0, following the manufacturer's instructions (Amersham, Canada). The sequencing product were electrophoresed on a $6 \%$ polyacrylamide gel, at $2400 \mathrm{~V}$ for $4 \mathrm{~h}$. The autoradiograms were read manually and the sequences were entered in $\mathrm{M}$ acClade 3 ( $\mathrm{M}$ addison and Maddison, 1992) and aligned using Clustal V, Version 1.4 (H iggins et al., 1992; Thompson et al., 1994) followed by minor manual adjustments. In order to determine the length of each spacer, the sequences of ITS region of Peltigera and Nephroma were compared to available sequences of various fungi: Alternaria alternata (GenBank Accession $\mathrm{N}$ o. U 05195), Elsinoe australis (U 18057), Epichloe typhina (X62987), Gaeumannomyces graminis (U 08320), Leptosphaeria bicolor (U 04203), Sclerotiniaceae (C arbone and Kohn, 1993), Septoria nodorum (U 04237). Sequences were then submitted to the Genome Sequence $D$ ata B ase and the accession numbers are given in Table 1. Absolute distance matrices were obtained by using PAUP 3.1 (Swofford, 1993). The algorithm for distance measures ignores uncertain or missing characters, if they occur in one of the two taxa compared (Swofford, 1993). N eighborjoining trees were constructed from "p-distances," that is the proportion of nucleotide site at which two sequences compared are different (Kumar et al., 1993), using M E GA software package (K umar et al., 1993). To determine the nature of the sequenced product obtained from total lichen DNA, identified $5.8 \mathrm{~S}$ sequences of Peltigera and Nephroma were then compared by neighbor-joining (p-distances) to available $5.8 \mathrm{~S}$ sequences of several fungi [i.e., Alternaria alternata (U 05195), Fusarium sambucinum (X65477), Gaeumannomyces graminis (U 08320), Sclerotinia sclerotiorum (M96382), Septoria nodorum (U 04237)], and algae [i.e., Chlamydomonas reinhardtii (X65621), Cladophora vagabunda (Z38134), and Gloeotilopsis planctonica (Z28970)] retrieved from Genbank.

\section{RESULTS}

The size of the fragment generated using total lichen D N A ranged from approximately 950 bp for N ephroma to $1050 \mathrm{bp}$ for Peltigera, which is comparable to that found for other ascomycetes (E gger, 1995). Comparison of the $5.8 \mathrm{~S}$ sequences obtained from total lichen extracts with that of various fungi and algae shows that the "lichen" sequences are more similar to fungal than to the algal sequences (F ig. 2). Amplification products derived from the DNA of each photomorph of a single pair appeared identical in size with electrophoresis. The sequencing reactions for species of Peltigera yielded alignable sequences between 545 (P. malacea) and 553 (P. aphthosa 1) nucleotides (nt) long (Table 2). Thirty positions of these 3848 nt $(0.78 \%$ of complete matrix) could not be scored with confidence, were left as ambiguous, and are automatically excluded from absolute distance values given below. Aligning the sequences of Peltigera species required the inclusion of 79 positions to accommodate insertions or deletions (indels). Comparison with published ITS and $5.8 \mathrm{~S}$ sequences allowed for the delimitation of the position of both spacers and the $5.8 \mathrm{~S}$ gene. The size of spacers 1 and 2 varies between species by 15 and 12 nt, respectively (Table 2). The $\mathrm{G}+\mathrm{C}$ content varies between 37.3 to $44.1 \%$ in the first spacer and 38.0 to $40.3 \%$ in the ITS-2. Within the $5.8 \mathrm{~S}$ gene, five positions are affected by indels, with, however, only a 2-nt difference in overall length, between the species. For the noncoding regions, the absolute distances between each pair of sequences, measured as the number of variable characters scored and excluding indels and uncertainties, varies between 0 (within each pair of photomorphs and among all samples of P. aphthosa) to 99 (between P. malacea and P. leucophlebia; Table 3). Of the 213 positions assigned to the ITS-1, 90 (=42\%) are variable and 36 of these ( $17 \%$ of total) only vary by the presence of an indel in at least one taxon. In the ITS-2, 30 $(13 \%)$ of $81(37 \%)$ polymorphic characters are invariant except for the indel. When excluding the indels and uncertainties, the $5.8 \mathrm{~S}$ gene varies only between $\mathrm{P}$. leucophlebia and all other taxa and among the three samples of P. leucophlebia (Table 3). Polymorphism is found at 16 positions (10\%) of the coding region, and indels distinguish taxa at only $6(4 \%)$ of these sites. Overall, mutations prior or subsequent to indels are found in 7 characters. The sequence of $P$. britannica differs from that of $P$. aphthosa by 3 point mutations and 3 insertions, with all except one point mutation located in the ITS-1. The joined cyanoand chloromorphs of "P. leucophlebia" differ in their ITS sequences from other samples of P. leucophlebia, but share identical sequences with $P$. aphthosa (Table 3). Peltigera malacea is phenetically closer to $P$. aphthosa than to P. leucophlebia (F ig. 3; Table 3). No intraspecific variation was detected between the two specimens of P. aphthosa, but 9 changes were recorded among the three specimens of P. leucophlebia $(1,2,3$; Table 3$)$. The variation found within P. leucophlebia $(1,2,3)$ was much less than the interspecific divergence found within Peltigera.

F or the species of N ephroma, sequences of 490 to $510 \mathrm{nt}$ 
were generated. Aligning the sequences required introducing an additional 32 sites to accommodate indels. It was not possible to determine the beginning of spacer 1 nor the end of spacer 2 and therefore no intraspecific distance measures were computed for these regions. The $5.8 \mathrm{~S}$ gene is $159 \mathrm{nt}$ long and starts at position 206. Among the species of Nephroma, the nucleotide sequence of the $5.8 \mathrm{~S}$ varies only by a 1-nt indel and one point mutation (less than $2 \%$ variation in total). The comparison between Nephroma and Peltigera also required numerous indels that did not allow a reliable alignment of the sequences. Consequently, no distance measures, except for the $5.8 \mathrm{~S}$ region were calculated.

\section{DISCUSSION}

The $5.8 \mathrm{~S}$ gene is common to all eukaryotes and is homologous to a portion of the 235 gene of prokaryotes (Jacq, 1981). The sequence of the $5.8 \mathrm{~S}$ gene is highly conserved and because of its small size it yields characters that are most useful in resolving relationships of taxa that have diverged prior to the Paleozoic (Hillis and Dixon, 1991), such as fungi and photosynthesizing organisms (K noll, 1992). A comparison of the $5.8 \mathrm{~S}$ gene sequences obtained from total lichen D N samples with those from fungi and algae suggests a higher similarity between "Iichen" and fungal sequences than between the former and algal sequences (F ig. 2). We can therefore assume that the primer NL6A annealed preferentially, if not exclusively, to fungal DNA and that the sequences of the ITS region derived from an amplified product using this primer in the presence of total lichen DNA, correspond to the nucleotide sequence of the mycobiont. Attempts to amplify the ITS region from pure algal DNA using the ascomycete-specific primer N L 6A did not yield any products (results not shown), supporting the hypothesis that the sequences obtained with total lichen DNA extracts truly belong to the mycobiont.

The sequence of the transcribed spacers varies between putatively related taxa of Peltigera and Nephroma, but exhibits little variation, if any, between conspecific sam-

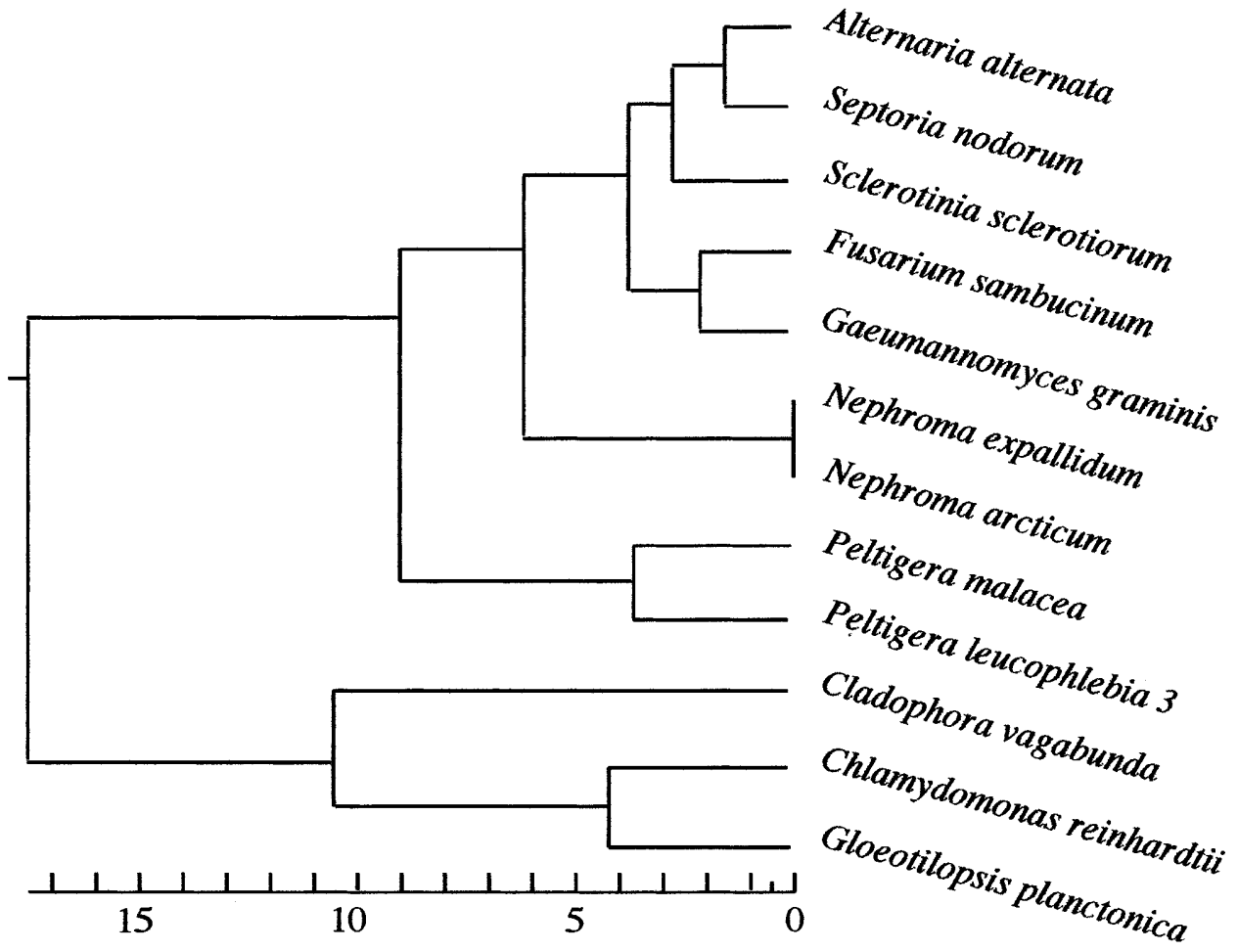

FIG. 2. Neighbor-joining analysis of $5.8 \mathrm{~S}$ gene sequences of Nephroma arcticum, N. expallidum, Peltigera leucophlebia 3, and P. malacea to selected algae and fungi. The $5.8 \mathrm{~S}$ sequences of the lichen were obtained from PCR products amplified from total lichen D N A extracts. The neighbor-joining tree is constructed using p-distances; i.e., the proportion of differences (K umar et al., 1993). 
TABLE 2

L ength (in N ucleotides) and GC Ratio (\% of Sequence Excluding Uncertain Characters) of the ITS-1, ITS-2, and 5.8S Gene in the Genus Peltigera

\begin{tabular}{lcccc}
\hline & ITS 1 & $5.8 S$ & ITS 2 & total \\
\hline 1. P. malacea & $193(38.3)$ & 155 & $197(39.1)$ & 545 \\
2. P. aphthosa 1 & $201(37.3)$ & 155 & $197(38.6)$ & 553 \\
3. P. aphthosa 2 chloromorph & $201(37.3)$ & 155 & $197(38.4)$ & 553 \\
4. P. aphthosa 2 cyanomorph & $201(37.3)$ & 155 & $197(38.4)$ & 553 \\
5. P. "leucophlebia" chloromorph & $201(37.3)$ & 155 & $197(38.4)$ & 553 \\
6. P. "leucophlebia" cyanomorph & $201(37.3)$ & 155 & $197(38.4)$ & 553 \\
7. P. britannica chloromorph & $202(39.6)$ & 155 & $197(40.3)$ & 554 \\
8. P. britannica cyanomorph & $202(39.6)$ & 155 & $197(40.3)$ & 554 \\
9. P. leucophlebia 1 & $187(44.1)$ & 153 & $208(38.3)$ & 548 \\
10. P. leucophlebia 2 & $186(43.0)$ & 154 & $209(38.1)$ & 549 \\
11. P. leucophlebia 3 & $186(43.5)$ & 154 & $208(38.0)$ & 548 \\
\hline
\end{tabular}

ples (Table 3; Fig. 3). The only report of the cyanomorph of P. leucophlebia (Goward et al., 1995) was based on the collection included in this study. The ITS sequences for both of the photomorphs present in that collection are identical to those of P. aphthosa. The specimens are rather poorly developed, and had originally been determined on the basis of thallus chemistry (G oward, personal communication), which earlier appeared to be more congruent with that of $P$. leucophlebia, but is now known to overlap with that of P. aphthosa (Goward et al., 1995). We therefore conclude that the putative photomorphs of $\mathrm{P}$. leucophlebia should be assigned to P. aphthosa. Consequently, the cyanomorph $\mathrm{P}$. leucophlebia remains unknown. The strict identity of ITS sequences of joined photomorphs supports the hypothesis that within the putative photomorph pairs of P. aphthosa, P. britannica, and N. arcticum the cyanoand the chloromorph share the same mycobiont species. Whether photomorphs should therefore by considered phenotypes of a single genotype - an implicit assumption made by Brodo and Richardson (1978) who interpreted the two photomorphs as alternative life strategies-is not clear. N ucleotide sequence variation of the ITS is generally low within a species (Baldwin et al., 1995; Gardes et al., 1991; Gardes and Bruns, 1993; Sanders et al., 1995), with exceptions known mainly from algae (Bakker et al., 1992; Kooistra et al., 1992; Adachi et al., 1994; Coleman et al., 1994; Ward et al., 1994; Zechman et al., 1994) and phytopathogenic fungi (O'D onnell, 1992; M orales et al., 1993; Poupard et al., 1993). ITS data therefore generally do not provide insights into the distribution of the overall genetic diversity of a species among its populations. The complete identity of the ITS sequences between two samples may thus suggest that the photomorphs are conspecific, but we cannot exclude the hypothesis that these individuals may represent distinct genotypes of a single species.

A genetic distinction of attached photomorphs is, however, difficult to rationalize. Photomorphs of Peltigera for example are most frequently, if not exclusively, joined. Genotypic heterogeneity between these thalli could occur (1) through somatic mutations in the putative gene controlling the selection of either photobiont or in the gene controlling its expression or (2) through the fusion of two thalli (or mycelia) early in their development ( $F$ ahselt, 1996). The first explanation seems very unlikely since

TABLE 3

Absolute D istance M atrix of Sequences of B oth Spacers (ITS-1 and ITS-2; below D iagonal) and of the 5.8S Gene (above D iagonal), among Species of Peltigera

\begin{tabular}{|c|c|c|c|c|c|c|c|c|c|c|c|}
\hline & 1 & 2 & 3 & 4 & 5 & 6 & 7 & 8 & 9 & 10 & 11 \\
\hline 1. P. malacea & - & 0 & 0 & 0 & 0 & 0 & 0 & 0 & 9 & 8 & 8 \\
\hline 2. P. aphthosa 1 & 11 & - & 0 & 0 & 0 & 0 & 0 & 0 & 9 & 8 & 8 \\
\hline 3. P. aphthosa 2 chloromorph & 11 & 0 & - & 0 & 0 & 0 & 0 & 0 & 9 & 8 & 8 \\
\hline 4. P. aphthosa 2 cyanomorph & 11 & 0 & 0 & - & 0 & 0 & 0 & 0 & 9 & 8 & 8 \\
\hline 5. P. "leucophlebia" chloromorph & 11 & 0 & 0 & 0 & - & 0 & 0 & 0 & 9 & 8 & 8 \\
\hline 6. P. "leucophlebia” cyanomorph & 11 & 0 & 0 & 0 & 0 & - & 0 & 0 & 9 & 8 & 8 \\
\hline 7. P. britannica chloromorph & 12 & 3 & 3 & 3 & 3 & 3 & - & 0 & 9 & 8 & 8 \\
\hline 8. P. britannica cyanomorph & 12 & 3 & 3 & 3 & 3 & 3 & 0 & - & 9 & 8 & 8 \\
\hline 9. P. leucophlebia 1 & 95 & 95 & 95 & 95 & 95 & 95 & 96 & 96 & - & 1 & 1 \\
\hline 10. P. leucophlebia 2 & 99 & 99 & 99 & 99 & 99 & 99 & 100 & 100 & 4 & - & 0 \\
\hline 11. P. leucophlebia 3 & 97 & 97 & 97 & 97 & 97 & 97 & 98 & 98 & 1 & 1 & - \\
\hline
\end{tabular}

Note. Polymorphic characters are scored as uncertainties; sites with uncertainties or missing data in one of the sequences compared were excluded from the distance measures. 


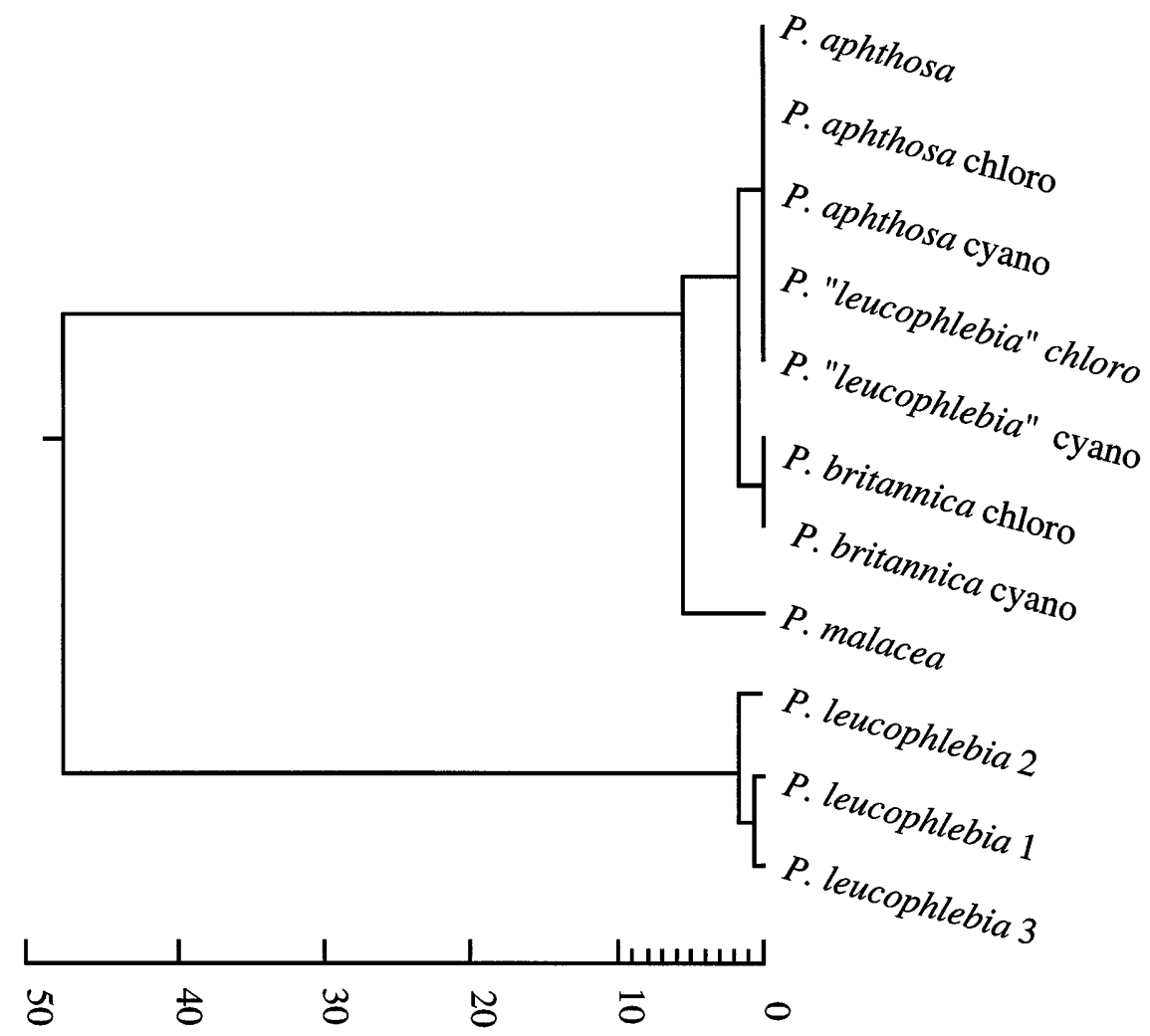

FIG. 3. Neighbor joining analysis of sequences of the ITS region (excluding the $5.8 \mathrm{~S}$ gene) for alternative photomorphs of P. aphthosa, P. britannica, P. leucophlebia, and the cyanolichen P. malacea. The ITS sequences of the lichen were obtained from PCR products amplified from total lichen D N A extracts. The neighbor-joining tree is constructed using p-distances; i.e., the proportion of differences (Kumar et al., 1993).

"homologous" somatic mutations would have to occur independently and repeatedly in all photomorphic chloromorphs prior to the development of cyanomorphic lobes. Thallus fusion, the basis for the second hypothesis, has been demonstrated with the fusion of soredia during the asexual reproductive cycle of Peltigera didactyla (With.) L aund. (Stocker-Wörgötter and Türk, 1990) and has been suggested as accounting for chemical hybrids between the two varieties of this species (G offinet and $H$ astings, 1995). Since alternative photomorphs of a single pair rarely occur independently, particularly in the species studied here, thallus fusion would be a prerequisite for the development of cyanomorphs in Peltigera and Nephroma. In the absence of data supporting a genotypic differentiation of photomorphs, the most parsimonious interpretation would be to regard them as phenotypes of a single genotype.

Recent ontogenetic studies on P. aphthosa (L.) Willd. and P. leucophlebia ( $\mathrm{N}$ yl.) Gyelnik reveal that the development of the main, green cephalodiate thallus is initiated from a prothallus including Nostoc as the sole photobiont (Stocker-Wörgötter and Türk, 1994; Yoshimura et al.,
1994), and this initial symbiotic stage involving cyanobacteria seems obligatory for all chlorophilous Peltigerineae (H oltan-H artwig, 1996). The simultaneous symbioses between a mycobiont and one prokaryotic and one eukaryotic photobiont, combined with the exclusive or preferential symbiosis at different stages of the life history, with the cyanobacterium or the green alga, respectively, suggests that the selection of a photobiont is genetically controlled. The two genes (e.g., one per photobiont) that would be involved would not be homologous since they may be expressed simultaneously. The nature of the primary photobiont thus varies with the developmental stage of these lichens. Considering further that not all chlorolichens of the Peltigerineae are known to be photomorphic (e.g., P. leucophlebia see above; and P. aphthosa in part of its range; see for example $\mathrm{H}$ oltan- $\mathrm{H}$ artwig, 1993), leads to suggesting that photomorphism - the ability of a mycobiont to develop a thallus with either a green alga or a cyanobacterium - must have a genetic basis, too. Applied to the P. aphthosa-group, the following hypotheses regarding a genetic differentiation of photomorphism can now be 
raised: (1) all populations of P. aphthosa have the potential to develop alternative photomorphs, and $\mathrm{P}$. aphthosa and $P$. leucophlebia differ genetically by their ability to develop photomorphs; (2) thalli of P. aphthosa that produce or have the potential to produce cyanomorphs are genetically distinct from those that do not. In order to better understand the evolutionary significance of photomorphism, we therefore need to examine not only the genetic structure of photomorphic species but also their phylogenetic relationship to congeneric taxa.

In addition to the photomorph hypothesis, our data also have some taxonomic and evolutionary implications for the genus Peltigera. H oltan-H artwig (1993) recently included P. malacea, a species lichenized only with a cyanobacteria, in the P. aphthosa-group, which has traditionally been restricted to taxa with green algae as primary and cyanobacteria as secondary photobionts. ITS sequence data provide evidence for a close relationship between P. malacea and P. aphthosa (Table 3; Fig. 3), even though a broader sampling of taxa would be necessary for a definite inclusion of this taxon in the P. aphthosa-group. The taxonomy within the P. aphthosa group has also undergone several recent changes with the recognition of $P$. britannica and P. leucophlebia as species distinct from P. aphthosa (Vitikainen, 1981; Tønsberg and $\mathrm{H}$ oltan-H artwig, 1983). The circumscription of the highly variable $P$. aphthosa is still subject to debate. While Thomson (1984) and Vitikainen (1994) question the taxonomic status of P. leucophlebia and P. britannica, respectively, others suggest recognizing new entities (H oltan-H artwig, 1993; G oward et al., 1995). The taxonomy of this group relies mostly on continuous variation of morphological characters (see treatment in $\mathrm{H}$ oltanH artwig, 1993; Vitikainen, 1994; Goward et al., 1995). Secondary chemistry offers an additional source of information, but is not well studied from taxa outside of E urope. Currently accepted concepts recognize a morphologically and chemically variable P. aphthosa, while other species of the $P$. aphthosa-group exhibit little variation in these characters (H oltan-H artwig, 1993; G offinet and H astings, 1994; Vitikainen, 1994; G oward et al., 1995). ITS sequence data support the taxonomic distinction of P. leucophlebia and P. britannica from P. aphthosa, even though the P. britannica differs proportionally much less from P. aphthosa than does P. leucophlebia (Table 3). The molecular divergence between $P$. aphthosa and $P$. leucophlebia is stronger than expected from chemical and particularly morphological differentiation. Considering that these two species may be more "distantly" related (F ig. 3) than previously thought (Thomson, 1984, see above), our data suggest that changes in morphological characters may be strongly selected against in the evolution of the P. aphthosa-group. Alternatively, molecular and morphological evolution could be decoupled, resulting in large genetic divergences associated with speciation (Vilgalys and Johnson, 1987; B runa et al., 1996, and references therein). In either case, genetic divergence may be further enhanced by ancient diversification of the genus. F ossil evidence supporting an ancient origin of the genus is lacking, but the Peltigerineae have been considered an ancient lineage by $\mathrm{H}$ awksworth (1988a, b) and Galloway (1991) on the basis of the rich lichenicolous fungi flora restricted to its species and the great chemical diversity found within and among its genera. Thorough monographic treatment of this group is needed for these evolutionary hypotheses to be further investigated using molecular techniques, such as restriction fragment length polymorphism of the small subunit of the nrD N A repeat (D ePriest 1993a, b; Beard and DePriest, 1996) or enzyme polymorphism (F ahselt, 1991).

The present study demonstrates the applicability of fungus specific primers for the amplification of the ITS region of the $\operatorname{nrDNA}$ repeat of lichenized mycobionts using total lichen DNA extracts. Comparisons of ITS sequences obtained for joined photomorphs of Peltigera and Nephroma suggests that lichenized mycobionts of a cyanomorph-chloromorph pair belong to a single species. Although ITS sequence data do not provide any insights into the intraspecific genotypic diversity, the most parsimonious interpretation of photomorphs is to regard them as phenotypes of a single genotype. Whether photomorphism or the ability to select either a green algae or a cyanobacterium as primary photobiont in (part of) the mature thallus is itself environmentally induced or genetically determined is not clear and needs to be addressed further by integrating population genetic and phylogenetic studies.

\section{ACKNOWLEDGMENTS}

This project would not have been possible without the permission of Keith Egger (St. John) to use the ascomycete-specific primer (NLA6) prior to its publication. Special thanks are also due to Trevor Goward (UBC) for the loan of specimens for D N A extractions and for continuous encouragements. Louise Lewis (DUKE) kindly shared a protocol for DNA extraction that we used on bryophytes prior to this study. We are grateful to Catherine La F arge-E ngland, John W. Taylor, D ale Vitt, and two anonymous reviewers for their judicious comments on an earlier version of the manuscript. This study was made possible by NSERC Grant A3797 to R.J.B., as well as by Grant A6390 to D ale Vitt. 


\section{REFERENCES}

Adachi, M ., Sako, Y., and I shida, Y. R estriction fragment length polymorphism of ribosomal DNA internal transcribed spacer and 5.85 regions in J apanese Alexandrium species (D inophyceae). J. Phycol. 30: 857-863.

Armaleo, D ., and Clerc, P. 1991. Lichen chimeras: D N A analysis suggests that one fungus forms two morphotypes. Exp. M ycol. 15: 1-10.

Bakker, F. T., Olsen, J. L., Stam, W. T., and van den Hoek, C. 1992. N uclear ribosomal D NA internal transcribed spacer regions (ITS 1 and ITS 2) define discrete biogeographic groups in Cladophora albida (Chlorophyta). J. Phycol. 28: 839-845.

Baldwin, B. G., Sanderson, M. J., Porter, J. M., Wojciechowski, M. F., Campbell, C. S., and D onoghue, M . J. 1995. The ITS region of nuclear ribosomal DNA: A valuable source of evidence of angiosperm phylogeny. Ann. M issouri Bot. Gard. 82: 247-277.

Beard, K. H., and DePriest, P. T. 1996. Genetic variation within and among mats of the reindeer lichen, Cladina subtenuis. Lichenologist 28: $171-182$.

Brodo, I. M., and Richardson, D. H. S. 1978. Chimeroid associations in the genus Peltigera. Lichenologist 10: 157-170.

Bruna, E. M., Fischer, R. N., and Case, T. J. 1996. M orphological and genetic evolution appear decoupled in Pacific skinks (Squamata: Scincidae: E moia). Proc. Roy. Soc. L ond. Biol. Sci. (B) 263: 681-688.

Buckler, E. S., and Holtsford, T. P. 1996. Zea ribosomal repeat evolution and substitution patterns. M ol. Biol. Evol. 13: 623-632.

Carbone, I., and Kohn, L. M. 1993. Ribosomal DNA sequence divergence within the internal transcribed spacer 1 of the Sclerotiniaceae. Mycologia 85: 415-427.

Coleman, A. W., Suarez, A., and G off, L. J. 1994. M olecular delineation of species ad syngens in volvocacean green algae (Chlorophyta). J. Phycol. 30: $80-90$.

D ePriest, P. T., and Been, M. D. 1992. N umerous Group I introns with variable distributions in the ribosomal D NA of a lichen fungus. J. $\mathrm{M} \mathrm{ol}$. Biol. 228: 315-321.

D ePriest, P. T. 1993a. Small subunit rD N A variation in a population of lichen due to optional group-I introns. Gene 134: 67-74.

D ePriest, P. T. 1993b. M olecular innovations in lichen systematics: The use of ribosomal intron nucleotide sequences in the Cladonia chlorophaea complex. Bryologist 96: 314-325.

D oyle, J. J., and D oyle, J. L. 1987. A rapid DNA isolation procedure for small quantities of fresh leaf tissue. Phytochem. Bull. 19: 11-15.

E gger, K. N . 1995. M olecular analysis of ectomycorrhizal fungal communities. Can. J. Bot. 73 (Suppl.1): S1415-S1422.

Fahselt, D. 1991. Enzyme similarity as an indicator of evolutionary divergence: Ster eocaulon saxatile H. M agn. Symbiosis 11: 119-130.

Fahselt, D. 1996. Individuals, populations and population ecology. In Lichen Biology (T. H. Nash III, Ed.), pp. 181-198. Cambridge Univ. Press, Cambridge.

Galloway, D . J. 1988. Studies in Pseudocyphellaria (lichens). I. The N ew Zealand species. Bull. Br. M us. Nat. Hist. (Bot.) 17: 1-267.

Galloway, D. J. 1991. Chemical evolution in the order Peltigerales: triterpenoids. Symbiosis 11: 327-344.

Galloway, D . J. 1994. Studies on the lichen genus Sticta (Schreber) Ach.: I. Southern South American species. Lichenologist 26: 223-282.

Gardes, M., White, T. J., F ortin, J. A., Bruns, T. D ., and Taylor, J. W. 1991.
I dentification of indigenous and introduced symbiotic fungi in ectomycorrhizae by amplification of nuclear and mitochondrial ribosomal D N A. Can. J. Bot. 69: 180-190.

Gardes, M ., and Bruns, T. D . 1993. ITS primers with enhanced specificity for basidiomycetes-Application to the identification of mycorrhizae and rusts. M olecular E cology 2: 113-118.

Gargas, A., and Taylor, J. W. 1992. Polymerase chain reaction (PCR) primers for amplifying and sequencing nuclear 185 rDNA from lichenized fungi. Mycologia 84: 589-592.

G offinet, B., and H astings, R. I. 1995. Two new sorediate taxa of Peltigera. Lichenologist 27: 43-58.

Goward, T., G offinet, B., and Vitikainen, O. 1995. Synospis of the genus Peltigera (lichenized Ascomycetes) in British Columbia, with a key to the N orth American species. Can. J. B ot. 73: 91-111.

H awksworth, D. L. 1988a. The variety of the fungal-algal symbiosis, their evolutionary significance, and the nature of lichens. Bot. J. Linn. Soc. 96: 3-20.

H awksworth, D . L . 1988b. Coevolution of fungi with algae and cyanobacteria in lichen symbioses. In Coevolution of Fungi with Plants and Animals (Pirozynki, K. A., and H awksworth, D . L., E ds.), pp. 125-148. Academic Press, San D iego.

H ibbett, D. S. 1992. Ribosomal RNA and fungal systematics. Trans. M ycol. Soc. Jpn 33: 533-556.

H iggins, D. G., Bleasby, A. J., and F uchs, R. 1992. Clustal V: I mproved software for multiple sequence alignment. Comp. Appl. Biosciences 8: 189-191.

Hillis, D. M., and Dixon, M. T. 1991. Ribosomal DNA: Molecular evolution and phylogenetic inference. Quart. Rev. Biol. 66: 411-453.

$\mathrm{H}$ oltan- $\mathrm{H}$ artwig, J. 1993. The lichen genus Peltigera, exclusive of the $\mathrm{P}$. canina group, in N orway. Sommerfeltia 15: 1-77.

H oltan-H artwig, J. 1996. E arly development in the natural habitat of chlorophilous species within the order Peltigerales. The third symposium of the International Association of Lichenology: Progress and Problems in Lichenology in the N ineties: 54. [Abstract]

$\mathrm{H}$ onegger, R. 1982. Cytological aspects of triple symbiosis in Peltigera aphthosa. J. Hatt. Bot. Lab. 52: 379-391.

$\mathrm{H}$ onegger, R. 1985. Fine structure of different types of symbiotic relationships in lichens. In Lichen Physiology and Cell Biology (D. H. Brown, E d.), pp. 287-302. Plenum Press, N ew York.

Jacq, B. 1981. Sequence homologies between eukaryotic 5.8S rR N A and the $5^{\prime}$ end of prokaryotic $23 \mathrm{~S}$ rRNA: Evidences for a common evolutionary origin. Nucleic Acids Res. 11: 2871-2880.

Jahns, H. M. 1988. The establishment, individuality and growth of lichen thalli. Bot. J. Linn. Soc. 96: 21-29.

James, P., and Henssen, A. 1976. The morphological and taxonomic significance of cephalodia. In Lichenology: Progress and Problems (D. H . Brown, D. L. H awksworth, and R. H . Bailey, E ds.), pp. 27-77. Academic Press, L ondon.

Jordan, W. P. 1972. E rumpent cephalodia, an apparent case of phycobial influence on lichen morphology. J. Phycol. 8: 112-117.

Knoll, A. H. 1992. The early evolution of eukaryotes: A geological perspective. Science 256: 622-627.

Kooistra, W. H. C. F., Stam, W. T., Olsen, J. L., and van den Hoek, C. 1992. Biogeography of Cladophorus membranacea (Chlorophyta) based on comparisons of nuclear nrDNA ITS sequences. J. Phycol. 28: $660-668$ 
Kumar, S., Tamura, K., and N ei, M . 1993. ME GA: M olecular Evolutionary Genetic Analysis, Version 1.0. Pennsylvania State University, U niversity Park.

L aundon, J. R. 1995. On the classification of lichen photomorphs. Taxon 44: 387-389.

L eizerovich, I., Kardish, N., and Galun, M. 1990. Comparison between eight symbiotic, cultured $\mathrm{Nostoc}$ isolates and a free-living Nostoc by recombinant D N A. Symbiosis 8: 75-85.

Liu, J.-S., and Schardl, C. L. 1994. A conserved sequence in internal transcribed spacer 1 of plant nuclear rRNA genes. PI. Mol. Biol. 26: 775-778.

Maddison, W. P., and Maddison, D. R. 1992. M acClade: Analysis of Phylogeny and Character E volution, Version 3.0. Sinauer, Sunderland.

M essner, R., Prillinger, H ., I bl, M ., and H immler, G. 1995. Sequences of ribosomal genes and internal transcribed spacers move three plants parasitic fungi, Eremothecium ashbyi, Ashbya gossypii, and Nematospora coryli, towards Saccharomyces cer evisiae. J. G en. A ppl. M icrobiol. 41: 31-42.

M orales, V. M., Pelcher, L. E ., and Taylor, J. L. 1993. Comparison of the 5.8S rDNA and internal transcribed spacer sequences of isolates of Leptosphaeria maculans from different pathogenicity groups. Curr. Genet. 23: 490-495.

M organ, D. R., and Soltis, D . E . 1993. Phylogenetic relationships among members of Saxifragaceae sensu lato based on $\mathrm{rbcL}$ sequence data. Ann. Missouri B ot. Gard. 80: 631-660.

$\mathrm{Niu}$, Y.-C., and Wei, J.-C. 1993. Variations in ITS2 sequences of nuclear rDNA from two Lasallia species and their systematic significance. M ycosystema 6: 25-29.

O 'D onnell, K. L. 1992. Ribosomal D N A internal transcribed spacers are highly divergent in the phytopathogenic ascomycete Fusarium sambucinum (G ibberella pulicaris). Curr. G enet. 22: 213-220.

Ott, S. 1988. Photosymbiodemes and their development in Peltigera venosa. Lichenologist 20: 361-368.

Poupard, P., Simonet, P., Cavelier, N ., and Bardin, R. 1993. M olecular characterization of Pseudocercosporella herpotrichoides isolates by amplification of ribosomal DNA internal transcribed spacers. Plant Pathol. 42: 873-881.

Renner, B. 1982. The presence or absence of secondary metabolites in cephalodia and their possible implications. J. Hatt. Bot. Lab. 52: 367-377.

Renner, B., and Galloway, D . J. 1982. Phycosymbiodemes in Pseudocyphellaria in N ew Zealand. M ycotaxon 16: 197-231.

Sande van der, C. A. F. M ., K wa, M ., van N ues, R. W., van H eerikhuizen, A., Raué, H. A., and Planta, R. J. 1992. F unctional analysis of internal transcribed spacer 2 of Saccharomyces cerevisiae ribosomal DNA. J. Mol. Biol. 223: 899-910.

Sanders, I., Alt, M., Groppe, K., Boller, T., and Wiemke, A. 1995. Identification of ribosomal DNA polymorphism among and within spores of the Glomales: Application to studies on the genetic diversity of arbuscular mycorrhizal fungal communities. New Phytol. 130: 419-427.

Sanger, F., N icklen, S., and Coulson, A. R. 1977. D N A sequencing with chain-terminating inhibitors. Proc. Natl. Acad. Sci. USA 74: 5463-5467.

Schlötterer, C., H auser, M.-T., von H aeseler, A., and Tautz, D. 1994.
Comparative evolutionary analysis of rD N A ITS regions in D rosophila. Mol. Biol. Evol. 11: 513-522.

Stocker-Wörgötter, E., and Türk, R. 1990. Thallus formation of the cyanobacterial lichen Peltigera didactyla from soredia under laboratory conditions. Bot. Acta 103: 315-321.

Stocker-Wörgötter, E., and Türk, R. 1994. Artificial resynthesis of the photosymbiodeme Peltigera leucophlebia under laboratory conditions. Crypt. Bot. 4: 300-308.

Swofford, D. L. 1993. Paup: Phylogenetic Analysis Using Parsimony, version 3.1.1. Computer Program distributed by the Illinois $\mathrm{N}$ atural $\mathrm{H}$ istory Survey, Champaign.

Tehler, A. 1996. Systematics, phylogeny and classification. In Lichen Biology (T. H. Nash III, Ed.), pp. 217-239. Cambridge Univ. Press, Cambridge.

Thompson, J. D., Higgins, D. G., and Gibson, T. J. 1994. Clustal W: Improving the sensitivity of progressive multiple alignment through sequence weighting, position-specific gap penalties and weight matrix choice. Nucleic Acid Res. 22: 4673-4680.

Thomson, J. W. 1984. American Arctic Lichens. 1. The Macrolichens. Columbia Univ. Press, N ew York.

Tønsberg, T., and H oltan-H artwig, J. 1983. Phycotype pairs in Nephroma, Peltigera and L obaria in N orway. N ord. J. Bot. 3: 681-688.

Torres, R. A., Ganal, M., and Hemleben, V. 1990. GC balance in the internal transcribed spacers ITS 1 and ITS 2 of nuclear ribosomal gens. J. Mol. Evol. 30: 170-181.

Vilgalys, R. J., and Johnson, J. L. 1987. Extensive genetic divergence associated with speciation in filamentous fungi. Proc. Natl. Acad. Sci. USA 84: 2355-2358.

Vitikainen, O. 1981. Peltigera Willd., nom. cons. In Bestimmungsschlüssel europäischer Flechten, E rgänzunsgheft II. Bibl. Lichen. 16: 236-242.

Vitikainen, O. 1994. Taxonomic revision of Peltigera (lichenized Ascomycotina) in E urope. Acta B ot. Fenn. 152: 1-96.

Ward, E ., Adams, M . J., M utasa, E. S., Collier, C. R., and Asher, M . J. C. 1994. Characterization of Polymoxa species by restriction analysis of PCR-amplified ribosomal D N A. Plant Pathol. 43: 872-877.

White, F. J., and James, P. W. 1987. Studies on the genus Nephroma II. The southern temperate species. Lichenologist 19: 215-268.

White, T. J., Bruns, T. D ., L ee, S. B., and Taylor, J. W. 1990. Amplification and direct sequencing of fungal ribosomal RN A genes for phylogenies. In PCR Protocols: A Guide to M ethods and Applications (M. A. Innis, D. H. Gelfand, J. J. Sninsky, and T. J. White, Eds.) pp. 315-322. Academic Press, N ew York.

Yoshimura, I., Kurokawa, T., Yamamoto, Y., and Kinoshita, Y. 1994. In vitro development of the lichen thallus of some species of Peltigera. Crypt. Bot. 4: 314-319.

Zambino, P. J., and Szabo, L. J. 1993. Phylogenetic relationships of selected ceral and grass rusts based on rDNA sequence analysis. M ycologia 85: 401-414.

Zechman, F. W., Zimmer, E . A., and Theriot, E . C. 1994. U se of ribosomal D NA internal transcribed spacers for phylogenetic studies in diatoms. J. Phycol. 30: 507-512.

Zimmermann, R. A., and D ahlberg, A. E. (Eds.) 1996. Ribosomal RNA: Structure, Evolution, Processing and Function in Protein Biosynthesis. CRC Press, Boca Raton. 